\title{
Determinants of Household Income and Willingness to Pay for Indigenous Plants in North West Province, South Africa: A Two-Stage Heckman Approach
}

\author{
Abiodun Olusola Omotayo ${ }^{1, *} \mathbb{0}$, Peter Tshepiso Ndhlovu ${ }^{2}\left(\mathbb{D}\right.$, Seleke Christopher Tshwene ${ }^{3}$, \\ Kehinde Oluseyi Olagunju 4 (D) and Adeyemi Oladapo Aremu ${ }^{1,2}$ (D) \\ 1 Food Security and Safety Niche Area, Faculty of Natural and Agricultural Sciences, North-West University, \\ Private Bag X2046, Mmabatho 2790, South Africa; Oladapo.Aremu@nwu.ac.za \\ 2 Indigenous Knowledge Systems (IKS) Centre, Faculty of Natural and Agricultural Sciences, \\ North-West University, Private Bag X2046, Mmabatho 2790, South Africa; Tshepiso.Ndhlovu@ump.ac.za \\ 3 Department of Agricultural Economics and Extension, Faculty of Natural and Agricultural Sciences, \\ North-West University, Private Bag X2046, Mmabatho 2790, South Africa; 16969669@nwu.ac.za \\ 4 Economics Research Branch, Agrifood and Biosciences Institute (AFBI), 18a Newforge Lane, \\ Belfast BT9 5PX, UK; kehinde-oluseyi.olagunju@afbini.gov.uk \\ * Correspondence: 25301284@nwu.ac.za; Tel.: +27-18-389-2573
}

check for updates

Citation: Omotayo, A.O.; Ndhlovu, P.T.; Tshwene, S.C.; Olagunju, K.O.; Aremu, A.O. Determinants of Household Income and Willingness to Pay for Indigenous Plants in North West Province, South Africa: A Two-Stage Heckman Approach. Sustainability 2021, 13, 5458.

https://doi.org/10.3390/su13105458

Academic Editor: Aaron K. Hoshide

Received: 10 March 2021

Accepted: 6 May 2021

Published: 13 May 2021

Publisher's Note: MDPI stays neutral with regard to jurisdictional claims in published maps and institutional affiliations.

Copyright: (c) 2021 by the authors. Licensee MDPI, Basel, Switzerland. This article is an open access article distributed under the terms and conditions of the Creative Commons Attribution (CC BY) license (https:/ / creativecommons.org/licenses/by/ $4.0 /)$.

\begin{abstract}
Using a cross-sectional dataset, this study examines the factors influencing the income and willingness to pay for indigenous plants by rural households in the North West Province of South Africa. The method of data analysis was based on a two-stage Heckman model. Based on empirical data, the majority (93\%) of the households are willing to pay for the indigenous plants. Furthermore, factors such as the age of the household's head, marital status, size of households, financial returns and economic benefit of indigenous plants significantly influenced income and willingness to pay for indigenous plants by the households. Thus, indigenous plants have the potential to penetrate local and international markets and can be used to improve the economies, livelihood, and food security status of rural households in South Africa. Indigenous plant cultivation can increase agro-food system species diversity while conserving plant species indigenous to this area of South Africa. Encouraging both consumption and production of indigenous plants can also help diversify local economies and communities.
\end{abstract}

Keywords: consumers' food preference; contingent valuation; purchasing power; market prospects; rural economy; sustainability

\section{Introduction}

Despite the acceleration in the state of technological advancement, the global food system is far behind the exponential increase in population thereby failing to meet the basic food needs and requirements of humans [1,2]. These challenges, as well as the on-going Covid-19 pandemic, have exerted multidimensional shocks on the global food system, thereby making achievements of Sustainable Development targets related to food security and hunger by 2030 doubtful $[3,4]$. The current global food system remains a diverse mixture of localized and industrialized systems of interconnected food chains $[5,6]$. However, most of these systems are centered on few exotic crop varieties with little role played by indigenous plants. Food systems supported through indigenous plants are easily sourced within a particular economy and, therefore, are potentially less vulnerable to economic, climatic, as well as the on-going Covid-19 pandemic shocks. The vulnerability related to dependence of a handful of exotic crops is particularly higher in the developing economies which are currently experiencing the effects, as well as of climate change and the unprecedented adverse effects of the Covid-19 pandemic [7-9]. 
Although South Africa has been embedded in the global agro-industrial food system for decades [1], its rural communities still suffer from poor nutritional status and extreme poverty. This indicates that such interconnectedness with global systems centered on exotic food crops may not solve the fundamental issues of malnutrition and hunger. Even though indigenous plants remain affordable sources of several micronutrients, the knowledge and use of these plants are currently low $[10,11]$. These plants are regarded as minor crops with little marketing and scientific attention [12]. Despite consolidation of the agro-industrial food system, South African food prices remain too high for a significant portion of the population, who consequently cannot afford to purchase adequate food, thereby leaving $21.3 \%$ of the population with low access to food [13].

The concerns regarding environmental degradation, loss of biodiversity, and vulnerability to climate change have prompted a call to rethink current configuration of the South African food system [14]. A focus on re-invigorating economic values and willingness to pay for indigenous plants, and bringing these to the market, has been suggested as an entry point for improving diets and making nutrition more sustainable [14,15]. According to some researchers [16-18], indigenous plants would fetch a higher price at supermarkets than in an informal market. One possible reason is that supermarkets are patronized by more nutritionally aware consumers with higher incomes who are more conscious of their health and are willing to pay higher prices to obtain these nutritional benefits $[18,19]$. It is also possible that the atmosphere in supermarkets influences prices and willingness to pay a premium price as they use modern retail technology in terms of storage, display, and packaging $[16,20,21]$. There is a scarcity of studies on the economics of indigenous plants, especially in South Africa. Even though there is no formal market for indigenous plants in the North West province, some anecdotal evidence suggests that there is a rising interest in purchasing such plants among households. The need to identify potential and create awareness for mainstreaming indigenous plants into the South African food system cannot be overemphasized.

Given this backdrop, the present study explored the knowledge of indigenous plants among rural households in the North West province of South Africa and examined factors determining their willingness to pay for indigenous plants. Understanding these determinants is vital in providing important information to promote and direct policy options towards production, adding value to and consumption of indigenous plants. Furthermore, findings from this study may provide potential traders of indigenous plants with important information about the socioeconomic factors influencing household willingness to pay and food consumption decisions, and as such contribute towards a more sustainable food system in South Africa.

\section{Willingness to Pay within the Theory of Consumer Choice}

The present section provides a brief discussion of competing theories and models of consumers' willingness to pay within the theory of consumer choices on which the analytical framework of this study was based.

\subsection{The Key Economic Model}

As explained by Ramasubramanian [22], willingness to pay for a particular product is the amount of money an individual or household is willing to pay to purchase a product given a person's income, risk preferences, and other factors. The two determinants of willingness to pay focused on by economic models are income of the individual or household and the use of the good in question. When individuals consider paying for improved environmental quality, such as forest and/or some of its products (e.g., indigenous plants), their choices and responses to valuation questions are constrained by their disposable income [21]. Therefore, a household or an individual's income is expected to correlate to be with the amount of money consumers are willing to spend for better environmental outcomes, such as indigenous plant conservation, by purchasing indigenous rather than non-native plants. 
Interestingly, income is mostly included in stated preference surveys and is expected to have a positive effect on consumer willingness to pay. Therefore, there is a direct behavioral link between the use of indigenous plants for consumption and the individual's well-being. This link is expressed by the concept of "use value." If an individual does not use the good (indigenous plants) in question, the only link between the good and the individual's well-being is the "knowledge" the individual has about the good [23]. This link is expressed as "non-use value", which is expected to be weaker than the link based on direct use. It is assumed that the willingness to pay for users is more than for nonusers [24].

\subsection{Transactions and Economic Potentials of Indigenous Plants}

Evidence of trading indigenous plants and their products varies from place to place, such as between different fruits, fruit juice, seedlings, and other by-products [22,23]. Indigenous fruits are sold in both urban and rural markets and provide a substantial income to small-scale farmers [24,25]. However, existing studies have revealed that the trading of fruits collected from the wild is a profitable enterprise [22]. For example, studies in Malawi, Tanzania, and Zimbabwe found that the percentage of net profit of indigenous fruit products reached $28 \%$ with higher profits being obtained in locations that are close to markets [22].

In South Africa, communities collectively harvested about 2000 metric tons of Sclerocarya birrea (A. Rich.) Hochst (Marula) and earned \$180,000 annually, representing more than $10 \%$ of average household income in these communities [26]. In addition, the members of a popular southern African Natural Products Trade Association reported gross revenue of $\$ 629,500$ from the sale of fruit tree products. The key fruit tree products were obtained from Sclerocarya birrea (A. Rich.) Hochst (Marula) and Adansonia digitata $\mathrm{L}$ (Baobab) that generated $\$ 126,420$ and $\$ 44,120$, respectively [22,27]. Based on a recent market projection, the potential market of Adansonia digitata was valued at $\$ 960$ million. Studies in Zimbabwe revealed that improvements in tree yield and earlier fruiting of indigenous fruit trees will create incentives for farmers to cultivate indigenous fruits [27].

Prior studies have found most participants indicating that indigenous plants (grains, vegetables, fruits) have favourable market potential $[23,28]$. Marketing costs of African leafy vegetables were estimated at between R0.50-R1.50/bundle with an average price paid by consumers of R10/bundle [29,30]. In another study [31], gender, education, marital status, and consumer perceptions influenced the purchasing decision for African leafy vegetables but not the level of expenditure. As highlighted by the authors, the identified factors influenced the purchasing decision but not the level of expenditure; such socio-economic characteristics were gender, educational and marital status, as well as perception factors.

\subsection{Theory of Planned Behavior}

Although economists rely on the concept of scale of preferences (choices) in order to determine what people value, sociologists have a strong affinity attitude (the desirability of a single action or object) [30,31]. A classical attitude-behavior paradigm would assume that behavior can be predicted by attitudes. This would mean that general attitudes such as environmental concern have a direct and positive effect on willingness to pay (See Figure 1). The basic attitude-behavior model is still part of thinking in social psychology although there are approaches going beyond this simple paradigm [21]. The intention to perform a behavior is the immediate determinant of the behavior in question, including the behavior of paying money for a good [32,33]. Prior research identified three determinants of the behavioral intention, such as attitude towards behavior, subjective norm, and perceived behavioral control [33]. The attitude towards behavior refers to an individual's positive or negative evaluation of performing the behavior. An individual's perception of social pressure from reference group members to enact the behavior is captured by the subjective norm. Perceived behavioral control includes perceived ease or difficulty of performing the behavior. Regarding indigenous plants, willingness to pay is expected 
to increase with a more favorable attitude towards paying, and with an increasing social pressure towards paying and with an increasing perceived behavioral control regarding paying for the indigenous plants [34-36].

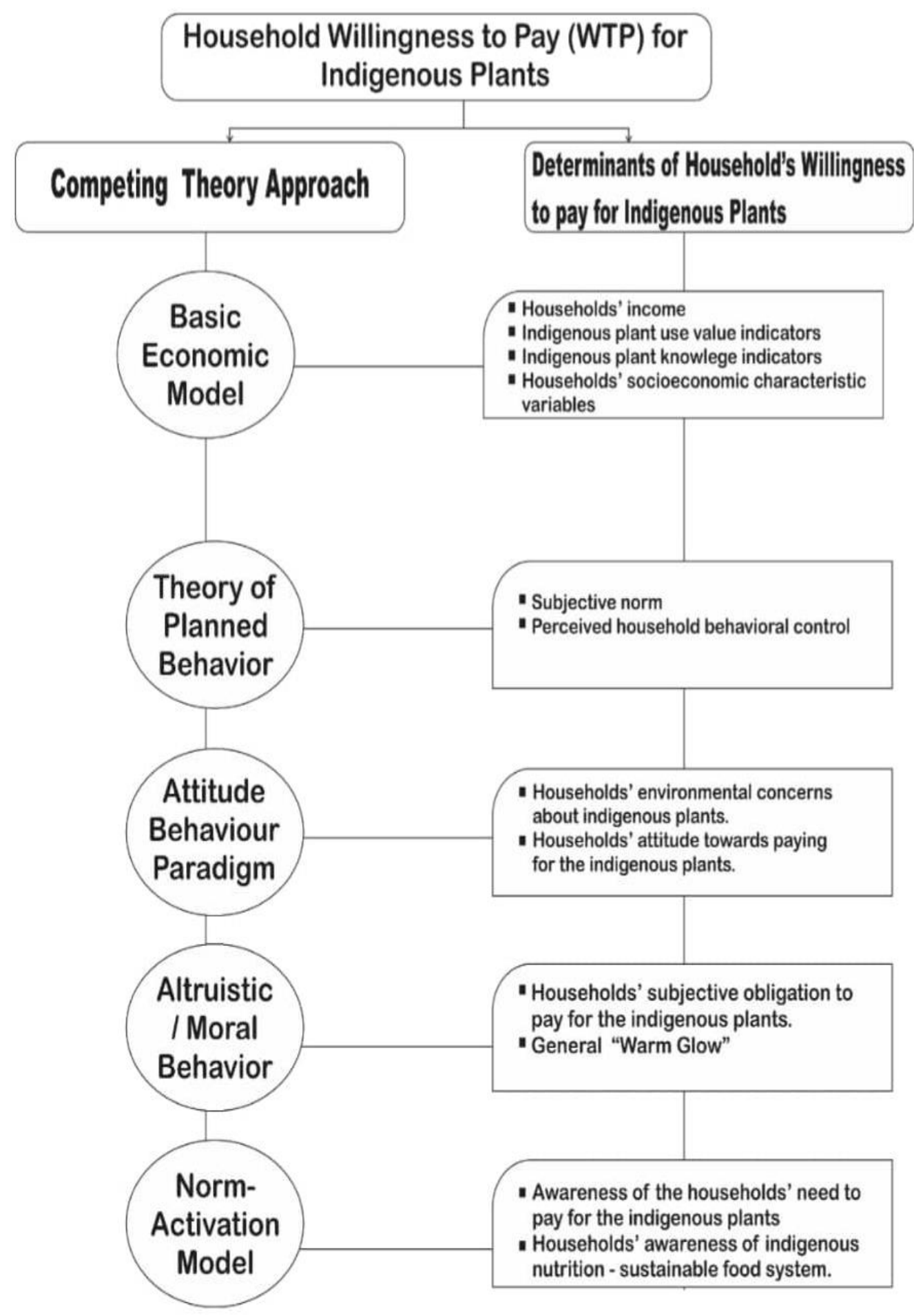

Figure 1. Framework for the theoretical approaches and determinants of households' willingness to pay for indigenous plants.

\subsection{Models of Altruistic and Moral Behavior}

Models of altruism are based on a broader motivational structure than standard economic models. One way to enable altruistic behavior in economic terms is to use a utility function that incorporates a taste for having other people better off or for having beneficial 
environmental attributes [23]. Altruistic motivation can lead to perceived obligations to contribute to the preservation of indigenous plants. These concepts can be used to explain what is known as the embedding effect [37], which is the observation that sometimes willingness to pay does not vary with the quantity of the good in question. If people only derive utility from the act of giving, then it does not matter what quantity of the good is provided. However, moral satisfaction may vary with the good as some goods give more satisfaction than others. There is empirical evidence for the purchase of moral satisfaction [37]. Willingness to pay can be positively affected by both a subjective obligation to pay for the specific good and a general warm glow which is independent of the specific good in question [21].

\subsection{Norm-Activation Model}

Given the awareness of need and awareness of responsibility, a perceived moral obligation can result in specific behavior. Both determinants mediate the effect of a perceived moral obligation on behavior $[21,38]$. In the context of willingness to pay analysis, the personal norm to pay for the good, the awareness of need with respect to providing the good, and the awareness of responsibility for paying are considered as behavioral determinants. The personal norm equals more or less the subjective obligation to pay which was discussed in the preceding models of altruistic behavior. It is expected that the awareness of need and the awareness of responsibility positively affect willingness to pay when considered as interaction terms with the subjective obligation to pay. Figure 1 presents a summary of the alternative theories and models and related determinants of willingness to pay discussed in previous sections, a combination of which is adopted in this article. Specifically, our study develops two econometric models for empirical analysis: a model of the determinants of a participant's income wherein knowledge and use of indigenous plants are included as explanatory variables along with other socio-demographic factors; and another model of the determinants of a participant's willingness to pay for indigenous plants. Both models were estimated using the two-stage Heckman approach.

\section{Methods}

\subsection{Study Area, Sampling Methods, Procedure, and Sample Size}

The study was conducted from all four district municipalities of the North West Province, South Africa. A multistage sampling procedure was used for data collection. Prior to the commencement of the survey, the enumerators were trained on the requirements of the survey and a pre-testing of the questionnaire was undertaken on a few rural households. In each of the selected communities, the traditional leaders provided access to the participants after consultation with them on the purpose and value of the research. Although the questionnaire was designed in English, interviews were conducted in the local languages of the participants, which include Setswana and Northern Sotho.

In the first stage of the sampling, four district municipalities (Ngaka Modiri Molema, Dr. Kenneth Kaunda, Bojanala Platinum, and Dr. Ruth Segomotsi Mompati) were selected. The second stage involved selecting 3 communities from each district municipality to account for the 12 communities studied. The selection of the 12 communities was based on their rural nature, active engagement in smallholder agricultural practices, and poor socioeconomic status of the residents. The last and final stage of sampling was the selection of rural household heads which was simplified by the assistance of resident extension officers. In this study, 133 sample households were utilized after a proper screening of the questionnaires. The allotted questionnaire samples for each selected community were representative, sufficiently robust and satisfactory to give estimates at the local level. Willingness to pay is generally analyzed using the contingent valuation (CV) method which helps to estimate value an individual places on a good. The contingent valuation method is originally designed to value goods and services where the market fails to adequately value these. This is mainly the case for public goods, the environment, and/or healthcare programs [39]. 
Generally, CV is referred to as a stated preference model, in contrast to a price-based revealed preference model [18]. The survey asks how much money people would be willing to pay (or willing to accept) to use (or be compensated for the loss of) organic food product features. Indeed, CV permits a direct estimation of willingness to pay by means of different elicitation techniques $[39,40]$. Consumers simply indicate their willingness to pay without purchasing the hypothetical product. As explained, the CV method relies on directly asking individuals about their willingness to pay for a specific commodity. The most important part in applying CV is to choose appropriate survey and elicitation methods to increase survey data accuracy [18]. Various survey methods and questionnaire formats are possible for collection of data. In-person interviews usually produce the highest-quality willingness to pay data, although telephone and mail surveys have been applied in several studies [41,42].

There are various techniques for eliciting consumers' willingness to pay. For instance, in a dichotomous-choice format, the participant is given a question to indicate the ability to pay X amount for the good, or not. Use of open-ended questions about a consumer's willingness to pay is another technique. An alternative method is to present several possible willingness to pay values on a card to the participant, knowns as a "payment card". The participant would choose the nearest quantity to their willingness to pay among others written on the card $[43,44]$. The chosen amount can be taken as the consumer's willingness to pay [18]. Since a payment card is simple, and it enlightens an unaware participant's picking options by giving them a range of predesigned price premiums, it is an appropriate approach in some studies $[40,44]$.

The data used in this paper were collected through a contingent valuation survey accompanied with a photo album to make plant identification easier for participants. Plants were identified within each category to which they belong. Our study used open-ended questions about the participants' willingness to pay for the indigenous plants. Participants were presented with the following willingness to pay question among others: Suppose your favorite indigenous plant has a price premium, would you pay? How much are you willing to pay? Can you pay $X$ amount for the purchase of this specific plant? These questions were asked in relation to different local price premiums in the study area. Prices vary by indigenous plant category (grain, fruits, vegetable, and beverages). In addition, the participants' willingness to pay parameter (dichotomous) was considered a dependent variable in this study. Households in the North West Province purchase indigenous plants from either farms or informal markets. In this study, 21 indigenous plants from 17 plant families were utilized, which were recorded as staple food, fruits, and beverages by the participants (Appendix A, Tables A1 and A2).

\subsection{Determinants of Households' Income and Willingness to Pay for Indigenous Plants}

To empirically analyze the determinants of households' income and willingness to pay for indigenous plants in the North West province of South Africa, a two-stage Heckman model was employed as detailed in previous studies [45-47]. The advantage of the application of the Heckman model is that it is able to model factors influencing households' income and their willingness to pay for indigenous plants in a single framework while simultaneously correcting for possible sample selection bias [48]. The first-stage equation of the Heckman model is a probit model, which assumes that the errors are homoscedastic [49].

$$
\begin{aligned}
& y_{1 i}=0 \text { if } S_{n i} \leq 0 \\
& y_{1 i}=1 \text { if } S_{n i}>0
\end{aligned}
$$

where $y_{1}$ is the binary response, $S_{n i}$ is the amount of money spent by the household $i$.

The spending equation can then be written as:

$$
y_{1}^{*}=\beta_{1 I} X_{1 I}+\varepsilon_{1 I}
$$


where $y_{1}^{*}$ is a latent variable, which is the utility the household will spend on indigenous plants. The binary model is then stated as:

$$
\left\{\begin{array}{c}
1, \text { if household spends on indigenuos plants } \\
0, \text { otherwise }
\end{array}\right.
$$

Specifically, the probit model in stage one of estimation is stated as

$$
\operatorname{Pr}\left(y_{1}\right)=f(x 1, x 2, \ldots \ldots \ldots x n)
$$

where $\operatorname{Pr}\left(y_{1}\right)$ is the probability of a household deciding to spend on indigenous plants or not, $x 1, x 2, \ldots \ldots \ldots \ldots n$ are the variables specified in Table 1 and $\varepsilon$ is the normally distributed error term. In the second stage of the Heckman model, ordinary least square (OLS) regression equations are estimated to test the effect of hypothesized factors on the on the extent of spending on indigenous plants. The model is stated as:

$$
\left(S_{n}\right)=f(y 1, y 2, \ldots \ldots \ldots . . . . y n, \varepsilon)
$$

where $S n$ is the amount of money spent on indigenous plants, $y 1, y 2, \ldots \ldots y n$ are the variables that were a priori hypothesized to affect the amount of money spent by the

\begin{tabular}{|c|c|}
\hline Variables & Description \\
\hline Age of the household's head & Number of years (Continuous) \\
\hline Gender of the household's head & Dummy; 1 if head is male and 0 if otherwise \\
\hline Educational status of the household's head & $\begin{array}{l}\text { Number of years of academic education } \\
\text { (Continuous) }\end{array}$ \\
\hline Marital status of the household's head & Dummy; 1 if head is married, 0 otherwise \\
\hline Household's size & $\begin{array}{l}\text { Number of members of the household } \\
\text { (Continuous) }\end{array}$ \\
\hline Number of working class & $\begin{array}{l}\text { Number who work and have income } \\
\text { (Continuous) }\end{array}$ \\
\hline $\begin{array}{l}\text { Involvement in agricultural practices by the } \\
\text { household }\end{array}$ & Dummy; 1 if yes, 0 otherwise \\
\hline Membership of cooperative society & Dummy; 1 if yes, 0 otherwise \\
\hline Land ownership & Dummy; 1 if lease, 0 otherwise \\
\hline Participation in training program & Dummy; 1 if yes, 0 otherwise \\
\hline Extension officer visit & Dummy; 1 if yes, 0 otherwise \\
\hline Knowledge of indigenous plants consumption & Dummy; 1 if yes, 0 otherwise \\
\hline Nutritious benefits of indigenous plants & Dummy; 1 if yes, 0 otherwise \\
\hline $\begin{array}{l}\text { Awareness of the drought-resistant benefits of } \\
\text { indigenous plants }\end{array}$ & Dummy; 1 if yes, 0 otherwise \\
\hline $\begin{array}{l}\text { Awareness of the pest-resistant nature of } \\
\text { indigenous plants }\end{array}$ & Dummy; 1 if yes, 0 otherwise \\
\hline Economic value benefits of indigenous plants & Dummy; 1 if yes, 0 otherwise \\
\hline Availability of indigenous plants & Dummy; 1 if yes, 0 otherwise \\
\hline Access to indigenous plants in local market & Dummy; 1 if yes, 0 otherwise \\
\hline Medicinal benefits of indigenous plants & Dummy; 1 if yes, 0 otherwise \\
\hline Household's financial returns & Dummy; 1 if yes, 0 otherwise \\
\hline
\end{tabular}
households on indigenous plants consumption, while $\varepsilon$ is the error term.

Table 1. Explanatory variables used in the models applied in the current study.

\subsection{Ethical Approval}

The Faculty of Natural and Agricultural Sciences research ethics committee (FNASREC) of the North-West University (NWU) approved (ethical clearance no: NWU-01243-19S9) the study. Permission to access the study area was granted by the North West Provincial Department of Rural, Environment and Agriculture (READ) in South Africa. Participation in the study was voluntary and conducted with full consent of the participants. 


\section{Results and Discussion}

\subsection{Demographic Characteristics of the Participants}

As shown in Table 2, the average age of household head is 47 years, suggesting that the sampled households are within their active years. This could be economically advantageous given that the active workforce falls within this age category in South Africa [50-52]. In addition, a larger proportion of households are headed by females $(56 \%)$, signifying the increasing roles of females in decision-making among households in the North West province. A similar finding was reported in previous studies [53,54]. Surprisingly, $44 \%$ of the heads of households are single despite their old age. Furthermore, the study indicated low educational attainment by the participants as only $35 \%$ of the participants completed a secondary level of education. Education plays a crucial role in the socioeconomic status of households and consciousness about environmental and food nutrition issues $[55,56]$.

Table 2. Socioeconomic characteristics of the participants.

\begin{tabular}{|c|c|c|c|}
\hline Variables & Frequency & Percentage (\%) & Mean (S.D) \\
\hline \multicolumn{4}{|l|}{ Age } \\
\hline $20-30$ & 11 & 8.30 & \\
\hline $31-40$ & 27 & 20.30 & \\
\hline $41-50$ & 38 & 28.60 & 47 (11.85) \\
\hline $51-60$ & 44 & 33.10 & \\
\hline $71-80$ & 13 & 9.80 & \\
\hline \multicolumn{4}{|l|}{ Gender } \\
\hline Male & 57 & 42.90 & \\
\hline Female & 75 & 56.40 & \\
\hline not disclosed & 1 & 0.80 & \\
\hline \multicolumn{4}{|l|}{ Marital status } \\
\hline Married & 47 & 35.30 & \\
\hline Single & 58 & 43.60 & \\
\hline Divorced & 14 & 10.50 & \\
\hline Widow(er) & 14 & 10.50 & \\
\hline \multicolumn{4}{|l|}{$\begin{array}{c}\text { Educational } \\
\text { attainment }\end{array}$} \\
\hline Standard & 38 & 28.60 & \\
\hline High school & 46 & 34.60 & \\
\hline Diploma & 19 & 14.30 & \\
\hline $\begin{array}{c}\text { Degree and } \\
\text { Postgraduate }\end{array}$ & 23 & 17.30 & \\
\hline No formal education & 7 & 5.30 & \\
\hline \multicolumn{4}{|l|}{ Race } \\
\hline Black & 132 & 99.20 & \\
\hline People of color & 1 & 0.80 & \\
\hline White & 0 & 0.00 & \\
\hline \multicolumn{4}{|l|}{$\begin{array}{c}\text { Household size } \\
\text { members }\end{array}$} \\
\hline $1-4$ & 55 & 41.35 & \\
\hline $5-8$ & 71 & 53.38 & $5(1.46)$ \\
\hline $9-12$ & 7 & 5.26 & \\
\hline
\end{tabular}


Table 2. Cont.

\begin{tabular}{|c|c|c|c|}
\hline Variables & Frequency & Percentage (\%) & Mean (S.D) \\
\hline \multicolumn{4}{|l|}{$\begin{array}{c}\text { Household head's } \\
\text { religion }\end{array}$} \\
\hline Christianity & 124 & 93.20 & \\
\hline Islam & 2 & 1.50 & \\
\hline Traditional worshiper & 6 & 4.50 & \\
\hline Others & 1 & 0.80 & \\
\hline \multicolumn{4}{|l|}{ Major occupation } \\
\hline Civil servants & 51 & 38.35 & \\
\hline Entrepreneur & 30 & 22.56 & \\
\hline Farmer & 28 & 21.05 & \\
\hline Others & 24 & 18.05 & \\
\hline \multicolumn{4}{|l|}{$\begin{array}{c}\text { Willingness to pay } \\
\text { for indigenous } \\
\text { plants }\end{array}$} \\
\hline Yes & 124 & 93.23 & \\
\hline No & 9 & 6.77 & \\
\hline \multicolumn{4}{|l|}{ Monthly income } \\
\hline R1000-3000 & 42 & 31.58 & \\
\hline R3001-6000 & 56 & 42.11 & ZAR7499/US\$510.82 \\
\hline R6001-9000 & 25 & 18.79 & $(11,134.85)$ \\
\hline R9001-12,000 & 10 & 7.52 & \\
\hline No of observations & 133 & & \\
\hline
\end{tabular}

In the current study, $99 \%$ of the participants were black, which reflects the ethnic demography of the North West province, currently dominated by black South Africans [57]. The average household size is five, indicating the potential that rural households in South Africa can supply labor and economically contribute to the South African economy. The household members can also help the head of household with cultivation of indigenous plants for more food secure rural regions in South Africa. Table 2 also reveals that the rural community participants were predominantly civil servants ( $38 \%$ of total), suggesting that a large proportion of households in the North West province depend on wage/salaried employment. Meanwhile, entrepreneur (23\%), farmers (21\%), and other $(18 \%)$ categories of occupation practiced in the study area is an indication of job diversification among the participants. The average income was estimated at R7499 (US\$510.82) in the study area. This is a relatively low income when evaluated from the household size perspective. Cultivation of indigenous plants could serve as additional source of income as well as a means for better food and nutrition within the marginalized rural poor of South Africa [18,58].

\subsection{Participants Willingness to Pay for Indigenous Plants}

Most (93.23\%) of the participants were willing to pay for indigenous plants for their consumption, while $6.77 \%$ were not willing to pay. This observation is consistent with findings from existing studies conducted in many provinces in South Africa [16,18]. This suggests a high potential demand and willingness to pay for indigenous plants by households in the North West Province of South Africa. Thus, there is potential for indigenous plants to gain a larger market share in the North West Province compared to their exotic counterparts.

\subsection{Two-Stage Heckman Model Results}

The Heckman two-stage approach was used to analyze the determinants of households' willingness to pay for indigenous plants, and subsequently, factors influencing household income. The first stage involves the application of the probit model, where 
the dependent variable is the household's willingness to pay. This variable is in binary form and takes the value of 1 if the household is willing to pay for indigenous plants and 0 otherwise. In the second stage, the ordinary least square (OLS) regression was applied where the log of a household's income is specified as the dependent variable.

Table 3 further presents the results of the Breusch-Pagen test for heteroscedasticity, with a test statistic of 13.33. When compared to a chi-squared distribution with one degree of freedom, the resulting $p$-value falls well below the standard 0.05 level. Thus, we have clear evidence to reject the null hypothesis of homoscedasticity and accept the alternative hypothesis that we do in fact have heteroscedasticity in the residual of this regression model.

Table 3. Determinants of income and willingness to pay for indigenous plants by households in North West Province.

\begin{tabular}{|c|c|c|c|c|}
\hline Variables & Coefficient & Standard Error & $\mathbf{Z}$ & $p>\mid \mathrm{z}$ \\
\hline \multicolumn{5}{|c|}{ Outcome Equation: [Determinants of household's income: ordinary least square regression] } \\
\hline $\begin{array}{l}\text { Age of the households' head } \\
\text { (years) }\end{array}$ & 0.05618 & 0.01617 & 3.47 & $0.001^{* * *}$ \\
\hline $\begin{array}{l}\text { Gender of the household's head } \\
\qquad(1=\text { male, } 0=\text { female })\end{array}$ & 0.05617 & 0.32896 & 0.51 & 0.607 \\
\hline $\begin{array}{l}\text { Educational status of the } \\
\text { household's head (years of } \\
\text { schooling) }\end{array}$ & -0.27232 & 0.83488 & -0.33 & 0.744 \\
\hline $\begin{array}{l}\text { Marital status of the household's } \\
\text { head (married }=1,0=\text { otherwise) }\end{array}$ & 0.84260 & 0.33143 & 2.54 & $0.011^{* *}$ \\
\hline Size of household (number) & 0.24601 & 0.13214 & 1.86 & 0.063 * \\
\hline Number of working class & -0.01905 & 0.16168 & -0.12 & 0.906 \\
\hline $\begin{array}{l}\text { Farming household }(1=\text { farming, } \\
0=\text { otherwise })\end{array}$ & -0.90351 & 0.46817 & -1.93 & $0.054^{*}$ \\
\hline $\begin{array}{c}\text { Membership of co-operative } \\
\text { society }(1=\text { member, } 0=\text { otherwise })\end{array}$ & -0.14177 & 0.52930 & -0.27 & 0.789 \\
\hline Land ownership (yes $=1$, no $=0$ ) & 0.31362 & 0.33471 & 0.94 & 0.349 \\
\hline $\begin{array}{l}\text { Participation in training program } \\
\qquad(\text { yes }=1, \text { no }=0)\end{array}$ & -0.03884 & 0.12217 & -0.32 & 0.751 \\
\hline $\begin{array}{l}\text { Visit by extension officers (yes }=1 \\
\text { no }=0 \text { ) }\end{array}$ & 1.14375 & 0.60564 & 1.89 & $0.059^{*}$ \\
\hline $\begin{array}{l}\text { Knowledge of indigenous plant } \\
\text { consumption (yes }=1 \text {, no }=0 \text { ) }\end{array}$ & -0.48173 & 0.64200 & -0.75 & 0.453 \\
\hline $\begin{array}{l}\text { Nutritional benefits of indigenous } \\
\text { plants (yes }=1, \text { no }=0 \text { ) }\end{array}$ & 0.45827 & 0.32879 & 1.39 & 0.163 \\
\hline $\begin{array}{l}\text { Drought-resistant trait of } \\
\text { indigenous plants }(\text { yes }=1, \text { no }=0 \text { ) }\end{array}$ & 0.66097 & 0.33952 & 1.95 & $0.052^{*}$ \\
\hline $\begin{array}{l}\text { Pest-resistant trait of indigenous } \\
\text { plants (yes }=1, \text { no }=0 \text { ) }\end{array}$ & 0.22832 & 0.32829 & 0.70 & 0.487 \\
\hline $\begin{array}{l}\text { Economic benefits of indigenous } \\
\text { plants (yes }=1, \text { no }=0)\end{array}$ & 0.78487 & 0.43004 & 1.83 & $0.068^{*}$ \\
\hline
\end{tabular}


Table 3. Cont.

\begin{tabular}{|c|c|c|c|c|}
\hline Variables & Coefficient & Standard Error & $\mathbf{Z}$ & $p>\mid z$ \\
\hline Constant & 3.72749 & 1.94571 & 1.92 & 0.055 \\
\hline \multicolumn{5}{|l|}{$\begin{array}{c}\text { Variables: fitted values of } \\
\text { log_Income } \\
\text { chi }^{2}(1)=13.33 \\
\text { Prob }>\text { chi }^{2}=0.0003\end{array}$} \\
\hline \multicolumn{5}{|c|}{ Selection Equation: Determinants of willingness to pay for indigenous crops: probit regression } \\
\hline $\begin{array}{l}\text { Age of the household's head } \\
\text { (years) }\end{array}$ & 0.00282 & 0.01688 & 0.17 & 0.868 \\
\hline $\begin{array}{l}\text { Marital status of the household's } \\
\text { head }(1=\text { married, } 0=\text { otherwise })\end{array}$ & -0.21769 & 0.39167 & -0.56 & 0.578 \\
\hline $\begin{array}{l}\text { Educational status of the } \\
\text { household's head (years of } \\
\text { schooling) }\end{array}$ & 0.70345 & 0.57533 & 1.22 & 0.221 \\
\hline $\begin{array}{l}\text { Farming household }(1=\text { farming } \\
0=\text { otherwise })\end{array}$ & -0.07060 & 0.57662 & -0.12 & 0.903 \\
\hline Size of household (number) & 0.39314 & 0.16221 & 2.42 & $0.015^{* *}$ \\
\hline $\begin{array}{l}\text { Accessibility to indigenous plants } \\
\qquad(\text { yes }=1, \text { no }=0)\end{array}$ & -0.55837 & 0.39234 & -1.42 & 0.155 \\
\hline $\begin{array}{l}\text { Extension officers visit (yes }=1, \\
\text { no }=0 \text { ) }\end{array}$ & -0.17523 & 0.69594 & -0.25 & 0.801 \\
\hline $\begin{array}{l}\text { Availability of indigenous plants in } \\
\text { local market (yes }=1, \text { no }=0)\end{array}$ & 0.05987 & 0.34684 & 0.17 & 0.863 \\
\hline $\begin{array}{l}\text { Economic benefits of indigenous } \\
\text { plants }(\text { yes }=1, \text { no }=0)\end{array}$ & 0.39823 & 0.41248 & 0.97 & 0.334 \\
\hline $\begin{array}{l}\text { Medicinal benefits of indigenous } \\
\text { plants (yes }=1, \text { no }=0 \text { ) }\end{array}$ & 1.42369 & 0.89110 & 1.60 & 0.110 \\
\hline $\begin{array}{l}\text { Financial returns for households } \\
\qquad(\text { yes }=1, \text { no }=0)\end{array}$ & 0.78573 & 0.42039 & 1.87 & $0.062 *$ \\
\hline Constant & -2.60987 & 1.39711 & -1.87 & 0.062 \\
\hline Number of observations & 133 & & & \\
\hline Lambda & 0.275024 & & & \\
\hline Wald chi ${ }^{2}(20)$ & 47.96 & & & \\
\hline Prob $>\mathrm{chi}^{2}$ & 0.0000 & & & \\
\hline Rho & 0.17590 & & & \\
\hline Sigma & 1.5635301 & & & \\
\hline
\end{tabular}

\subsubsection{Determinants of Household's Income: OLS Regression}

About $43 \%$ of the coefficients on the variables included in the model have expected signs and are statistically significant at the $10 \%$ level or more (Table 3 ). The age of the household's head is significant and positive $(p<0.01)$ which indicates that the participants' income increases with age, a proxy measure used to capture experience. This might be true as the increase in age of participants might translate into more experience which invariably translates into higher income. This corroborates with existing studies indicating earnings increases with increasing age, specialized skill trainings, and/or education of the household heads [58-60]. In addition, the results also show that marital status of the household head was positively and significantly related to income $(p<0.05)$. This implies that participants who are single are likely to have higher income relative to other categories 
of marital status. This could be attributed to the fact that they are likely to have more time to do more jobs, hence, have more time to work, thus earning more income than their married counterparts.

The coefficient of the household size is positive and significant $(p<0.05)$, meaning that participants with a large household size will likely have higher income. This is possible as households with mature and working-age members are likely to have higher income than large household with more dependent members [61,62]. The coefficient of involvement of households in agricultural activities is negative and significant $(p<0.10)$, which indicates that farming households in the study area earn relatively less than those who earns mainly from non-agricultural activities. This might be due to the fact that a large number of households are comprised of civil servants (Table 2) with potentially greater incomes than agricultural households. This is in line with a study in Nigeria that reported that non-farm income of households was more than on-farm income and hence, it has a direct effect on food security status $[63,64]$.

It is encouraging that extension visits positively and significantly $(p<0.10)$ influence households' income, which indicates that households with more access to extension officers were able to generate higher income from farming activities compared to their counterparts without such access $[65,66]$. The coefficient of the drought-resistant benefits of indigenous plants variable was positive and significant $(p<0.10)$, thereby exerting a positive effect on household income. This suggests that participants who are knowledgeable about the drought-resistant attributes of the indigenous plants are more likely to have higher income when cultivating indigenous plants. Similarly, the acknowledgement of economic benefits of indigenous plants had a positive and significant $(p<0.10)$ relation to household income. This is consistent with prior literature on the economic potential of indigenous plants to increase household income, lifting rural communities out of poverty and enhancing food security $[18,50,67-69]$.

\subsubsection{Probit Regression}

The probit model analysis identified the determinants of the willingness to pay for indigenous plants by the households (Table 3). The coefficient of household size was positive and significant $(p<0.05)$, indicating that participants with a large household size had a higher likelihood of paying for indigenous plants. This might be due to the expected food need for such a large household which will translate into willingness to pay for indigenous plants in the study area. In addition, this might be due to greater expected food needs for larger households, which can increase the demand and thus the willingness to pay for indigenous plants in the study area. However, this is contrary to prior studies which have found that encouraging people to have smaller families is associated with greater willingness and ability to pay for food [16]. The variable representing value of financial return of the households was positive and significant $(p<0.10)$, suggesting that the probability of the willingness to pay for indigenous plants by households increased with greater financial returns. This was expected, given that households with higher financial returns have the ability to pay for indigenous plants in order to ensure that their households are food secure. This observation is in line with basic economic consumer behavior related to income, expenditure, and savings [70,71].

\section{Policy Recommendations}

Based on the empirical findings of this study, the following policy recommendations remain pertinent since the majority (93\%) of the households were willing to pay for indigenous food plants, especially those that are larger in size. However, rural households cultivating indigenous plant species could have some added value and beneficial attributes arising from domestic cultivation of indigenous food plants. In this study, the economic benefits and returns from the indigenous plants were emphasized as significant variables in the model. This indicates that households that are cultivating these indigenous species give some added value or beneficial attributes. Public awareness through different media 
should be target-promoting the nutritional, and economic benefits of the indigenous plants which can help increase the demand. Moreover, households with lower willingness to pay can be properly oriented on the benefits of this indigenous plants, thereby increasing the overall households' willingness to pay for the indigenous crops. Hence, private markets, nongovernmental organizations and the governments need to be involved in the dissemination of information of the potential economic benefits of indigenous plants in order to enhance households' willingness to pay for them. Furthermore, the promotion of indigenous plants in local markets will promote communities' food-nutrition, socioeconomics, welfare, and health through a more diversified local economy. Particularly, quality education remained a principal legal and regulatory barrier to markets for indigenous plants. On this basis, the need to educate households to promote the production and consumption of indigenous plants which is capable of contributing to economic sustainability cannot be overemphasized. In addition, the average income was estimated at ZAR7499 (\$510.82) which was relatively low income when evaluated from the household size perspective. The study recommends that the government should implement policies that will grant lower-income households' permission to access wild indigenous plants on public lands if they are priced out of the local marketplace for these foods, so long as it is assured that they promote "stewardship" over these plants in the wild. This can also help in price control by the farmers of such indigenous plants. It could as well result in greater ecological diversity while improving food access issues, especially among the marginalized rural households. Furthermore, household size was repeatedly significant in the two stages of the model. There should be proper orientation of the rural households on the economic implications of large family sizes, as this can further placing such households in multidimensional poverty. Finally, as a result of the high diversity of indigenous plants in the study area, local communities should take advantage of a variety of plants that are more accessible or abundant to combat hunger and malnutrition. Therefore, government support to the farmers should emphasize target products and assist their production through national markets.

\section{Conclusions}

This study examined the factors influencing income and willingness to pay for indigenous plants by selected rural households in North West Province of South Africa. The majority (93\%) of the households who participated were willing to pay for indigenous food plants which suggests a high potential demand by households and market for indigenous plants in the province. In addition, an average age of 47 years, more (56\%) female-headed households and average monthly income of R7499 (\$510.82) was recorded in the study area. Empirical analysis revealed that factors such as age, marital status, household size, farming households, and economic benefits of indigenous plants influenced income and willingness to pay for indigenous plants by the households. Particularly, household size and financial returns were the significant determinants of the willingness to pay for indigenous plants by the participants. The study therefore concludes that socioeconomic characteristics are key determinants of households' willingness to pay for indigenous food plants in rural South Africa. This understanding will assist policy makers to implement agricultural and food policies, thereby addressing the food security, nutrition, and health sustainability. Future research on the breeding and value-adding activities to enhance the indigenous plants' cultivation, market accessibility, acceptability, and durability are necessary to encourage household's willingness to pay and consumption of indigenous plants. More so, a more nationally and globally representative dataset for studies on household's willingness to pay for indigenous plants needs to be compiled for future studies to provide further understanding of the subject matter. Such initiatives could have a positive societal value of reducing households' dependence on a handful of crops for nutrition, food security, and sustainability in the developing nations. 
Author Contributions: Conceptualization, A.O.O. and A.O.A.; funding acquisition; A.O.A.; investigation; A.O.O., S.C.T., and P.T.N.; project administration, A.O.A.; resources, A.O.A.; supervision, A.O.A.; writing original draft, A.O.O. and K.O.O.; writing review and editing, A.O.O., K.O.O., P.T.N., and S.C.T. All authors have read and agreed to the published version of the manuscript.

Funding: The research was partially funded by the National Research Foundation [NRF UID: 109508], Pretoria, South Africa and the Article Processing Charge was funded by the Faculty of Natural and Agricultural Sciences, North-West University, Mmabatho, South Africa.

Institutional Review Board Statement: The research was revised by the Institutional Review Board with ethic approval number NWU-01243-19-S9.

Informed Consent Statement: Informed consent was obtained from all subjects involved in the study.

Data Availability Statement: Data are available on request from the first author of the manuscript.

Acknowledgments: A.O.O. appreciates the Postdoctoral fellowship from the North-West University, Mmabatho, South Africa.

Conflicts of Interest: We declare no conflict of interest with regards to the current research. The opinions and conclusions/recommendations expressed in this work are that of the authors, and that the National Research Foundation accepts no liability whatsoever in this regard.

\section{Appendix A}

Table A1. Indigenous vegetables and grains consumed by the participants in selected rural households in North West Province. Number of mention (NM), Vernacular names: Ts = Setswana and $\mathrm{E}=$ English .

\begin{tabular}{cccc}
\hline $\begin{array}{c}\text { Scientific Name and } \\
\text { Family }\end{array}$ & Vernacular Name & Usage & NM \\
\hline $\begin{array}{c}\text { Amaranthus sp } \\
\text { Amaranthaceae }\end{array}$ & Amaranthus (E); Thepe (Ts) & Staple food & 71 \\
\hline $\begin{array}{c}\text { Cajanus cajan (L.) Millsp. } \\
\text { Leguminosae/Fabaceae }\end{array}$ & Pigeon bean (E); Dinawa (Ts) & Staple food & 26 \\
\hline $\begin{array}{c}\text { Cleome gynandra L } \\
\text { Cleomaceae }\end{array}$ & $\begin{array}{c}\text { Cat's whiskers, African } \\
\text { cabbage (E); Lerotho (Ts) }\end{array}$ & Staple food & 4 \\
\hline $\begin{array}{c}\text { Colocasia esculenta (L.) Schott } \\
\text { Araceae }\end{array}$ & $\begin{array}{c}\text { Potato of the tropics (E); } \\
\text { Madumbis (Ts) }\end{array}$ & Staple food & 3 \\
\hline $\begin{array}{c}\text { Glycine max (L.) Merr. } \\
\text { Leguminosae/Fabaceae }\end{array}$ & Soybeans (E); Dinawa (Ts) & Staple food & 57 \\
\hline $\begin{array}{c}\text { Lagenaria siceraria (Mol.) Standl. } \\
\text { Cucurbitaceae }\end{array}$ & Bottle gourd, Calabash (E); & Staple food \\
\hline $\begin{array}{c}\text { Manihot esculenta Crantz } \\
\text { Euphorbiaceae }\end{array}$ & Cassava (E); Muthupula (Ts) & Staple food & 8 \\
\hline $\begin{array}{c}\text { Tetragonia decumbens Mill. } \\
\text { Aizoaceae }\end{array}$ & Dune spinach (E) & Staple food & 32 \\
\hline $\begin{array}{c}\text { Sorghum bicolor (L.) Moench } \\
\text { Poaceae }\end{array}$ & Sorghum (E); Mabele (Ts) & Beverage and \\
staple food & 111 \\
\hline $\begin{array}{c}\text { Tylosema esculentum (Burch.) A. } \\
\text { Leguminosae/Fabaceae }\end{array}$ & Marama bean (E) & Staple food \\
\hline
\end{tabular}


Table A2. Indigenous fruits consumed by the participants in selected rural households in North West Province. Number of mention (NM), Vernacular names: Ts = Setswana and E = English.

\begin{tabular}{|c|c|c|c|}
\hline $\begin{array}{l}\text { Scientific Name and } \\
\text { Family }\end{array}$ & Vernacular Name & Usage & NM \\
\hline $\begin{array}{c}\text { Annona senegalensis Pers. } \\
\text { Annonaceae }\end{array}$ & $\begin{array}{l}\text { African Custard-apple (E); } \\
\text { Mokamanawe (Ts) }\end{array}$ & Fruit & 18 \\
\hline $\begin{array}{c}\text { Carissa macrocarpa (Eckl.) A. DC. } \\
\text { Apocynaceae }\end{array}$ & $\begin{array}{l}\text { Natal plum, big num-num } \\
\text { (E) }\end{array}$ & Fruit & 1 \\
\hline $\begin{array}{c}\text { Diospyros lycioides Desf. } \\
\text { Ebenaceae }\end{array}$ & $\begin{array}{c}\text { Monkey plum (E); Lethanyu } \\
(\mathrm{Ts})\end{array}$ & Fruit & 1 \\
\hline $\begin{array}{c}\text { Diospyros simii (Kuntze) De Winter. } \\
\text { Ebenaceae }\end{array}$ & Climbing Star-apple (E) & Fruit & 2 \\
\hline $\begin{array}{c}\text { Dovyalis caffra (Hook.f. \& Harv.) } \\
\text { Sim } \\
\text { Salicaceae }\end{array}$ & Kei-apple (E) & Fruit & 0 \\
\hline $\begin{array}{c}\text { Dovyalis zeyheri (Sond.) Warb. } \\
\text { Salicaceae }\end{array}$ & Wild apricot $(E)$ & Fruit & 1 \\
\hline $\begin{array}{l}\text { Mimusops zeyheri Sond } \\
\text { Sapotaceae }\end{array}$ & $\begin{array}{l}\text { Transvaal red milkwood (E); } \\
\text { Mmupudu (Ts) }\end{array}$ & Beverage & 53 \\
\hline $\begin{array}{c}\text { Parinari curatellifolia Planch. ex } \\
\text { Benth. } \\
\text { Chrysobalanaceae }\end{array}$ & Bosappel (A); Mobola (Ts) & Fruit & 4 \\
\hline $\begin{array}{c}\text { Sclerocarya birrea (A. Rich.) Hochst. } \\
\text { Anacardiaceae }\end{array}$ & Marula (E); Morula (Ts) & $\begin{array}{l}\text { Fruit and } \\
\text { beverage }\end{array}$ & 71 \\
\hline $\begin{array}{l}\text { Strychnos spinosa Lam. } \\
\text { Loganiaceae }\end{array}$ & $\begin{array}{c}\text { Corky-bark Monkey-orange } \\
\text { (E); Morapa (Ts) }\end{array}$ & Fruit & 8 \\
\hline $\begin{array}{c}\text { Vangueria infausta Burch. } \\
\text { Rubiaceae }\end{array}$ & $\begin{array}{l}\text { Chirinda wild-medlar, (E); } \\
\text { Mobilo (Ts) }\end{array}$ & Fruit & 15 \\
\hline
\end{tabular}

\section{References}

1. Mabhaudhi, T.; Chibarabada, T.; Chimonyo, V.; Murugani, V.; Pereira, L.; Sobratee, N.; Govender, L.; Slotow, R.; Modi, A. Mainstreaming underutilized indigenous and traditional crops into food systems: A South African perspective. Sustainability 2019, 11, 172. [CrossRef]

2. Borelli, T.; Hunter, D.; Padulosi, S.; Amaya, N.; Meldrum, G.; Beltrame, D.M.d.O.; Samarasinghe, G.; Wasike, V.W.; Güner, B.; Tan, A. Local solutions for sustainable food systems: The contribution of orphan crops and wild edible species. Agronomy 2020, 10, 231. [CrossRef]

3. Albert, J.R.G.; Abrigo, M.R.M.; Quimba, F.M.A.; Vizmanos, J.F.V. Poverty, the Middle Class, and Income Distribution Amid COVID-19; Philippine Institute for Development Studies: Quezon City, Philippine, 2020.

4. Otekunrin, O.A.; Otekunrin, O.A.; Fasina, F.O.; Omotayo, A.O.; Akram, M. Assessing the Zero Hunger Target Readiness in Africa in the Face of COVID-19 Pandemic. Caraka Tani J. Sustain. Agric. 2020, 35, 213-227. [CrossRef]

5. Ackerman, K.; Conard, M.; Culligan, P.; Plunz, R.; Sutto, M.-P.; Whittinghill, L. Sustainable food systems for future cities: The potential of urban agriculture. Econ. Soc. Rev. 2014, 45, 189-206.

6. Anderson, C.R.; Bruil, J.; Chappell, M.J.; Kiss, C.; Pimbert, M.P. From transition to domains of transformation: Getting to sustainable and just food systems through agroecology. Sustainability 2019, 11, 5272. [CrossRef]

7. Van Bavel, J.J.; Baicker, K.; Boggio, P.S.; Capraro, V.; Cichocka, A.; Cikara, M.; Crockett, M.J.; Crum, A.J.; Douglas, K.M.; Druckman, J.N. Using social and behavioural science to support COVID-19 pandemic response. Nat. Hum. Behav. 2020, 4, 460-471. [CrossRef]

8. Capano, G.; Howlett, M.; Jarvis, D.S.L.; Ramesh, M.; Goyal, N. Mobilizing Policy (In)Capacity to Fight COVID-19: Understanding Variations in State Responses. Policy Soc. 2020, 39, 285-308. [CrossRef]

9. Silva, P.C.L.; Batista, P.V.C.; Lima, H.S.; Alves, M.A.; Guimarães, F.G.; Silva, R.C.P. COVID-ABS: An agent-based model of COVID-19 epidemic to simulate health and economic effects of social distancing interventions. ChaosSolitons Fractals 2020, 139, 110088. [CrossRef]

10. Van der Hoeven, M.; Osei, J.; Greeff, M.; Kruger, A.; Faber, M.; Smuts, C.M. Indigenous and traditional plants: South African parents' knowledge, perceptions and uses and their children's sensory acceptance. J. Ethnobiol. Ethnomed. 2013, 9, 1-12. [CrossRef] 
11. Kuhnlein, H.V.; Receveur, O. Dietary change and traditional food systems of indigenous peoples. Annu. Rev. Nutr. 1996, 16, 417-442. [CrossRef]

12. Weinberger, K.; Lumpkin, T.A. Diversification into horticulture and poverty reduction: A research agenda. World Dev. 2007, 35, 1464-1480. [CrossRef]

13. Stats, S.A. Provincial Profile: North West Community Survey 2016; Statistics South Africa: Pretoria, South Africa, 2018 ; pp. 1-93.

14. Drimie, S.; Pereira, L. Advances in food security and sustainability in South Africa. In Advances in Food Security and Sustainability; Elsevier: Amsterdam, The Netherlands, 2016; Volume 1, pp. 1-31.

15. Pereira, L.M. The future of South Africa's food system: What is research telling us. SA Food Lab. S. Afr. 2014. Available online: https:/ / bio-economy.org.za/wp-content/uploads/2015/02/Pereira-2014-The-Future-of-South-Africas-Food-SystemReport.pdf (accessed on 11 May 2021).

16. Chelang'a, P.K.; Obare, G.A.; Kimenju, S.C. Analysis of urban consumers' willingness to pay a premium for African Leafy Vegetables (ALVs) in Kenya: A case of Eldoret Town. J. Food Secur. 2013, 5, 591-595. [CrossRef]

17. Ngugi, I.K.; Gitau, R.; Nyoro, J. Access to High Value Markets by Smallholder Farmers of African Indigenous Vegetables in Kenya; Regoverning Markets Innovative Practice Series; IIED: London, UK, 2007.

18. Senyolo, G.M.; Wale, E.; Ortmann, G.F. Consumers' Willingness-To-Pay for underutilized vegetable crops: The case of African leafy vegetables in South Africa. J. Hum. Ecol. 2014, 47, 219-227. [CrossRef]

19. Parsa, H.G.; Lord, K.R.; Putrevu, S.; Kreeger, J. Corporate social and environmental responsibility in services: Will consumers pay for it? J. Retail. Consum. Serv. 2015, 22, 250-260. [CrossRef]

20. Ramasubramanian, J.A. Willingness to pay for index based crop microinsurance in India. DPhil Candidate (Economics); University of Sussex: Brighton, UK, 2012.

21. Liebe, U.; Preisendörfer, P.; Meyerhoff, J. To pay or not to pay: Competing theories to explain individuals' willingness to pay for public environmental goods. Environ. Behav. 2011, 43, 106-130. [CrossRef]

22. Ham, C.; Akinnifesi, F.K.; Franzel, S.; Jordaan, D.; Hansmann, C.; Ajayi, O.; De Kock, C. Opportunities for commercialization and enterprise development of indigenous fruits in southern Africa. In Indigenous Fruit Trees in the Tropics: Domestication, Utilization and Commercialization; World Agroforestry Centre: Nairobi, Kenya; CAB International Publishing: Wallingford, UK, 2007; pp. 254-272.

23. Omotayo, A.O.; Aremu, O.A. Evaluation of factors influencing the inclusion of indigenous plants for food security among rural households in the North West Province of South Africa. Sustainability 2020, 12, 9562. [CrossRef]

24. Shai, K.N.; Ncama, K.; Ndhlovu, P.T.; Struwig, M.; Aremu, A.O. An exploratory study on the diverse uses and benefits of locally-sourced fruit species in three villages of Mpumalanga Province, South Africa. Foods 2020, 9, 1581. [CrossRef]

25. Muhanji, G.; Roothaert, R.L.; Webo, C.; Stanley, M. African indigenous vegetable enterprises and market access for small-scale farmers in East Africa. Int. J. Agric. Sustain. 2011, 9, 194-202. [CrossRef]

26. Ham, C. Plant for food and drink. Southern African Trade Directory of Indigenous Natural Products. Commercial Products from the Wild Group. Stellenbosch 2005, 1, 17-22.

27. Mithofer, D.; Waibel, H.; Akinnifesi, F.K. The Role of Food from Natural Resources in Reducing Vulnerability to Poverty: A Case Study from Zimbabwe. 2006. Available online: https:/ / ageconsearch.umn.edu/record/25264/ (accessed on 11 May 2021).

28. Senyolo, G.M.; Wale, E.; Ortmann, G.F. A double hurdle analysis of consumers' decisions to purchase African leafy vegetables in Limpopo province. J. Consum. Sci. 2019, 4, 10-21.

29. Senyolo, G.M.; Wale, E.; Ortmann, G.F. Analysing the value chain for African leafy vegetables in Limpopo Province, South Africa. Cogent Soc. Sci. 2018, 4, 1509417. [CrossRef]

30. Green, C.; Tunstall, S. A Psychological Perspective; Oxford University Press: Oxford, UK, 1999.

31. Kahneman, D.; Ritov, I.; Schkade, D.; Sherman, S.J.; Varian, H.R. Economic preferences or attitude expressions?: An analysis of dollar responses to public issues. In Elicitation of Preferences; Springer: New York, NY, USA, 1999; pp. $203-242$.

32. Ajzen, I. The theory of planned behavior. Organ. Behav. Hum. Decis. Process. 1991, 50, 179-211. [CrossRef]

33. Ajzen, I.; Brown, T.C.; Rosenthal, L.H. Information bias in contingent valuation: Effects of personal relevance, quality of information, and motivational orientation. J. Environ. Econ. Manag. 1996, 30, 43-57. [CrossRef]

34. Meyerhoff, J. Stated willingness to pay as hypothetical behaviour: Can attitudes tell us more? J. Environ. Plan. Manag. 2006, 49, 209-226. [CrossRef]

35. Moisseinen, E. On behavioural intentions in the case of the Saimaa Seal. Comparing the contingent valuation approach and the attitude-behaviour research. Valuation and the Environment: Theory, Method and Practice. 1999, pp. 183-204. Available online: https: / www.econbiz.de/Record/ on-behavioural-intentions-in-the-case-of-the-saimaa-seal-comparing-the-contingentvaluation-approach-and-attitude-behaviour-research-moisseinen-eija/10001365087 (accessed on 12 May 2021).

36. Rekola, E.; Mika, P. The theory of planned behavior in predicting willingness to pay for abatement of forest regeneration. Soc. Nat. Resour. 2001, 14, 93-106. [CrossRef]

37. Kahneman, D.; Knetsch, J.L. Valuing public goods: The purchase of moral satisfaction. J. Environ. Econ. Manag. 1992, 22, 57-70. [CrossRef]

38. Blamey, R. Contingent valuation and the activation of environmental norms. Ecol. Econ. 1998, 24, 47-72. [CrossRef]

39. Blumenschein, K.; Johannesson, M.; Yokoyama, K.; Freeman, P. Hypothetical versus real willingness to pay in the health care sector: Results from a field experiment. Value Health 2001, 4, 79. [CrossRef] 
40. Boccaletti, S.; Nardella, M. Consumer willingness to pay for pesticide-free fresh fruit and vegetables in Italy. Int. Food Agribus. Manag. Rev. 2000, 3, 297-310. [CrossRef]

41. Haghjou, M.; Hayati, B.; Pishbahar, E.; Mohammad, R.R.; Dashti, G.H. Factors affecting consumers'potential willingness to pay for organic food products in iran: Case study of Tabriz. J. Agric. Sci. Technol. 2013, 15, 191-202.

42. Weinberger, K. Indigenous Vegetables in Tanzania: Significance and Prospects; AVRDC-World Vegetable Center: Shanhua, Taiwan, 2004; Volume 600.

43. Fu, T.T.; Liu, J.T.; Hammitt, J.K. Consumer willingness to pay for low-pesticide fresh produce in Taiwan. J. Agric. Econ. 1999, 50, 220-233. [CrossRef]

44. Gil, J.M.; Gracia, A.; Sanchez, M. Market segmentation and willingness to pay for organic products in Spain. Int. Food Agribus. Manag. Rev. 2000, 3, 207-226. [CrossRef]

45. Goetz, S.J. A selectivity model of household food marketing behavior in sub-Saharan Africa. Am. J. Agric. Econ. 1992, 74, 444-452. [CrossRef]

46. Abdullah; Rabbi, F.; Ahamad, R.; Ali, S.; Chandio, A.A.; Ahmad, W.; Ilyas, A.; Din, I.U. Determinants of commercialization and its impact on the welfare of smallholder rice farmers by using Heckman's two-stage approach. J. Saudi Soc. Agric. Sci. 2019, 18, 224-233. [CrossRef]

47. Deressa, T.T.; Hassan, R.M.; Ringler, C. Perception of and adaptation to climate change by farmers in the Nile basin of Ethiopia. J. Agric. Sci. 2011, 149, 23-31. [CrossRef]

48. Tilahun, U.; Bedemo, A. Farmers' perception and adaptation to climate change: Heckman's two stage sample selection model. Ethiop. J. Environ. Stud. Manag. 2014, 7, 832-839. [CrossRef]

49. Winship, C.; Mare, R.D. Models for sample selection bias. Annu. Rev. Sociol. 1992, 18, 327-350. [CrossRef]

50. Omotayo, A.O.; Ndhlovu, P.T.; Tshwene, S.C.; Aremu, A.O. Utilization pattern of indigenous and naturalized plants among some selected rural households of North West Province, South Africa. Plants 2020, 9, 953. [CrossRef]

51. Kaona, F.A.D.; Tuba, M. A qualitative study to identify community structures for management of severe malaria: A basis for introducing rectal artesunate in the under five years children in Nakonde District of Zambia. BMC Public Health 2005, 5, 28. [CrossRef]

52. Mavhura, E.; Manyena, S.B.; Collins, A.E.; Manatsa, D. Indigenous knowledge, coping strategies and resilience to floods in Muzarabani, Zimbabwe. Int. J. Disaster Risk Reduct. 2013, 5, 38-48. [CrossRef]

53. Flatø, M.; Muttarak, R.; Pelser, A. Women, weather, and woes: The triangular dynamics of female-headed households, economic vulnerability, and climate variability in South Africa. World Dev. 2017, 90, 41-62. [CrossRef]

54. Tibesigwa, B.; Visser, M. Small-scale subsistence farming, food security, climate change and adaptation in South Africa: Malefemale headed households and urban-rural nexus. Econ. Res. S. Afr. Cape Town 2015, 527, 33.

55. Babar, N.F.; Muzaffar, R.; Khan, M.A.; Imdad, S. Impact of socioeconomic factors on nutritional status in primary school children. J. Ayub. Med. Coll. Abbottabad 2010, 22, 15-18. [PubMed]

56. Nkonki-Mandleni, B.; Ogunkoya, F.T.; Omotayo, A.O. Socioeconomic factors influencing livestock production among smallholder farmers in the free state province of south Africa. Int. J. Entrep. 2019, 23, 1-17.

57. Naude, W.; Serumaga-Zake, P. An analysis of the determinants of labour force participation and unemployment in South Africa's North-West province. Dev. S. Afr. 2001, 18, 261-278. [CrossRef]

58. Sigit, H. Income distribution and household characteristics. Bull. Indones. Econ. Stud. 1985, 21, 51-68. [CrossRef]

59. Ibrahim, H.; Rahman, S.A.; Envulus, E.E.; Oyewole, S.O. Income and crop diversification among farming households in a rural area of north central Nigeria. J. Agro-Sci. 2009, 8, 84-89. [CrossRef]

60. Omotayo, A.O. Farming households' environment, nutrition and health interplay in Southwest, Nigeria. Int. J. Sci. Res. Agric. Sci. 2016, 3, 84-98. [CrossRef]

61. Kamo, Y. Racial and ethnic differences in extended family households. J. Sociol. Perspect. 2000, 43, 211-229. [CrossRef]

62. Omotoso, A.B.; Daud, A.S.; Adebayo, R.A.; Omotayo, A.O. Socioeconomic determinants of rural households' food crop production in Ogun State, Nigeria. Appl. Ecol. Environ. Res. 2018, 16. [CrossRef]

63. Adelekan, Y.A.; Omotayo, A.O. Linkage between rural non-farm income and agricultural productivity in Nigeria: A tobit-twostage least square regression approach. J. Dev. Areas 2017, 51, 317-333. [CrossRef]

64. Omotayo, A.O. Economic Synergy between Rural Off-farm Income and Households' Poverty in Ekiti State, Nigeria. J. Hum. Ecol. 2016, 56, 99-106. [CrossRef]

65. Onubuogu, G.C.; Esiobu, N.S.; Nwosu, C.S.; Okereke, C.N. Resource use efficiency of smallholder cassava farmers in Owerri Agricultural zone, Imo State, Nigeria. Sch. J. Agric. Sci. 2014, 4, 306-318.

66. Olorunfemi, O.D.; Adekunle, O.A.; Oladipo, F.O.; Oladele, T.O.; Oladele, O.I. Training needs of fish farmers on value addition initiatives in Kwara State, Nigeria. Sarhad J. Agric. 2017, 33, 1-21. [CrossRef]

67. Akinnifesi, F.K.; Ajayi, O.C.; Sileshi, G.; Kadzere, I.; Akinnifesi, A.I. Domesticating and commercializing indigenous fruit and nut tree crops for food security and income generation in Sub-Saharan Africa. In Proceedings of the New Crops International Symposium, Southampton, UK, 1 September 2007.

68. Ndhlovu, P.T.; Omotayo, A.O.; Aremu, A.O.; Otang-Mbeng, W. Herbal-Based Cosmeceuticals and Economic Sustainability among Women in South African Rural Communities. Economies 2020, 8, 51. [CrossRef] 
69. Omotayo, A.O.; Aremu, A.O. Underutilized African indigenous fruit trees and food-nutrition security: Opportunities, challenges, and prospects. Food Energy Secur. 2020, 9. [CrossRef]

70. Johnstone, D.B.; Marcucci, P.N. Financing Higher Education Worldwide: Who Pays? Who Should Pay? The Johns Hopkins Univrsity Press: Baltimore, MD, USA, 2010.

71. Singh, U. Financial literacy and financial stability are two aspects of efficient economy. J. Financ. Account. Manag. 2014, 5, 59. 